\title{
Modifications of Bleomycin Induced Cytogenetic Damages by 2-Deoxy-D-Glucose on Normal and Tumor Cells
}

\author{
P. Venkatachalam*, V. R. Jayanth and Solomon F. D. Paul \\ Department of Human Genetics, Sri Ramachandra Medical College \& Research Institute \\ (Deemed University), Porur, Chennai 600 116, Tamil Nadu, India
}

KEYWORDS Bleomycin; chromosomal aberrations; micronucleus; glioma cells; 2-DG

\begin{abstract}
The radiomimetic drug bleomycin induced chromosomal aberrations (CA) and micronuclei (MN) were studied in peripheral blood lymphocytes (PBL), as reference to normal cells and Glioma (BMG -1) as reference to tumor cells, with and without exposure to 2-deoxy D- glucose (2-DG, an analogue of glucose). Treatment with bleomycin increased both CA and MN frequency in a dose dependent manner in both cell types. The frequencies of CA are 2 fold higher than $\mathrm{MN}$ for a given concentration of bleomycin. Exposure to bleomycin predominantly induced exchange type chromosome aberrations. While in the presence of 2-DG the aberrations induced by bleomycin reduced significantly in PBL, the same was increased significantly in BMG cells $(\mathrm{P}<0.001)$ showing a protective effect and sensitizing effect on normal and tumor cells respectively. The dose modulatory factor (protection) for different concentration of bleomycin exposure varied between 0.38 and 0.72 for $\mathrm{CA}$ and 0.1 and 0.84 for MN in PBL. In the case of BMG-1 cells, the modulatory factor (sensitization) varied between 1.42 and 2.59 for CA, 1.25 and 1.66 for $\mathrm{MN}$ at different concentration of bleomycin exposure. The modulatory effect of 2-DG was also evidenced from the coefficients obtained for the dose-response curves of the aberrations studied. The paper discusses the types of aberrations induced by bleomycin and the mechanism involved for differential modifications of cytogenetic damage by 2-DG in normal (PBL) and tumor (Glioma) cells.
\end{abstract}

\section{INTRODUCTION}

Chemotherapy given with curative or palliative intent, usually requires multiple cycles of treatment (Salpak and Kufe 1986), and is given mostly with the intention of destroying cancer cells wherever they may exist in the body. Treatment of tumors with chemotherapeutic drugs is thus not devoid of risk to the normal cells (Hall 2000). In fact there are reports on an increase in both spontaneous chromosome breakage and sister chromatid exchanges after chemotherapy (Obe et al. 1981; de Mesa et al. 2002).

In addition to radiotherapy, chemotherapy alone or in combination with radiation plays a pivotal role in the management of malignant diseases. An enhanced cytotoxic effect of combined bleomycin and radiotherapy was reported in animal models and in normal and tumor cells in vitro (Bleehen et al. 1974). The combined use of chemotherapy and radiotherapy may cause a degree of injury to the patients. Administration of same dose of a given drug to a

*Corresponding Author: P. Venkatachalam, Department of Human Genetics, Sri Ramachandra Medical College \& Research Institute (Deemed University), Porur, Chennai 600 116, Tamil Nadu, India

Fax: $91+044-4767008$

E-mail:venkip@yahoo.com population of patients results in a range of toxicity, from unaffected to lethal events. While many clinical variables have been associated with drug response, genetic differences in drug disposition and drug target can have great impact on treatment outcome (Watters et al. 2003). Furthermore, the types of lesions induced by the therapeutic agents, their repair, are varied within tissues, which determine the response of patients to therapy (Cloos et al. 1999; Vral et al. 2004).

The therapeutic potential of radiation is extensively studied and reviewed (Hall 2000). To maximize the therapeutic effect of radiation, studies were reported on the modulatory effect of compounds like Hoechst (Denison et al. 1992) cysteine (Pattet et al. 1949), caffeine (Franchitto et al. 1998) calcium channel blockers (Rajeeve et al. 1995) and 2-DG in animal models (Jain et al. 1979), glioma cells (Dwarakanath et al. 1989), breast tumor cells (Aft et al. 2002) followed by radiation and in tumor cells exposed to radionuclides (Shrivastava et al. 2006). Scrutiny of literature did not show any evidence for the modulatory effect of chemotherapeutic drugs though their use is inevitable in combined modality treatment. We have recently demonstrated a protective effect of 2-DG on bleomycin and mitomycn-C induced chromosomal aberrations and cell cycle proliferation in PBL (Venkatachalam et al. 2006). 
The present study was therefore extended to investigate the effects of 2-DG on bleomycin induced cytogenetic damages in normal and tumor (BMG-1) cells.

\section{MATERIALS AND METHODS}

Normal and BMG-1 Cells: The peripheral blood lymphocytes collected from healthy volunteers are used as normal cells and human cerebral glioma cells (BMG-1) constituted tumor cells. The BMG-1 cells were obtained from INMAS, Delhi, and maintained as a monolayer culture in our laboratory. Cells were grown in plastic tissue culture flasks using Dulbecco's modified essential medium supplemented with $5 \%$ fetal calf serum and antibiotics (Penicillin $50 \mathrm{IU} / \mathrm{ml}$, Streptomycin $35 \mu \mathrm{g} / \mathrm{ml}$ and Gentamycin $2.5 \mu \mathrm{g} / \mathrm{ml})$.

Exposures to BMG-1 Cells to Bleomycin: BMG-1 cells grown for 24 hours after subculture were treated with bleomycin at different concentrations $(10$ to $80 \mu \mathrm{g} / \mathrm{ml})$ in the presence and absence of 2-DG ( $5 \mathrm{mM}, 30$-min pretreatment to bleomycin) for 3 hours at $37^{\circ} \mathrm{C}$. At the end of 3 hours bleomycin and 2-DG were removed from the cells by washing with HBSS (Hanks Balanced Salt Solution) for 3 times. Cells were re-suspended in the medium, grown further for another 20 to 28 hours. Colchicine $(0.1 \mu \mathrm{g} / \mathrm{ml})$ was added at 20 hours to block the cells at metaphase. At the end of 28 hours, the cells were exposed to hypotonic solution $(0.45 \% \mathrm{KCl})$, washed with Carnoy's fixative (methanol and acetic acid 3:1) and were cast on pre-cooled slides. The slides were then stained with Giemsa and mounted with DPX. They were observed under microscope to record various types of aberrations like dicentric chromosome, ring chromosome, minutes, gaps, acentric fragments and chromatid gaps (IAEA Technical report 1986). From the aberration recorded, they are grouped into exchnage type (dicentrics and ring chromosomes) and total aberrations (chromatid type and chromosome type). For micronucleus assay cytochalasin-B at a final concentration of $2 \mu \mathrm{g} / \mathrm{ml}$ culture was added at 24 hours of culture. The cells are further incubated for 24 hours at $37^{\circ} \mathrm{C}$. The cells were harvested with brief hypotonic treatment and slides were prepared by fixing the cells with Carnoy's fixative. The cell suspensions were dropped on to a clear cooled slide and stained with Giemsa. Cells with two daughter nuclei surrounded by cytoplasm were scored for the presence of $\mathrm{MN}$ according to criteria of Paul et al. (1997).

Exposure to Peripheral Blood Lymphocytes to Bleomycin: The blood samples obtained from the volunteers were suspended in RPMI-1640 medium and treated with bleomycin at concentrations employed for BMG-1 cells with and without 2-DG. The cells were then washed with HBSS and were processed to obtain of metaphases as described elsewhere (Venkatachalam et al. 1999). Briefly, cultures were initiated with $1.0 \mathrm{ml}$ of the blood sample, $10 \mathrm{ml}$ culture medium (RPMI-1640) supplemented with 7.5\% NaHCO3, $20 \%$ fetal calf serum, $200 \mathrm{mM}$ L-Glutamine, penicillin 100 units $/ \mathrm{ml}$ and streptomycin $100 \mu \mathrm{g} /$ $\mathrm{ml}$ and $200 \mathrm{ml}$ of PHA-P. At 46 hours, the cells were blocked at metaphase by adding colcemid at a final concentration of $0.1 \mu \mathrm{g} / \mathrm{ml}$. The cultures were further incubated until 48 hours. The sample was harvested after hypotonic treatment (20 minutes with $0.45 \% \mathrm{KCl}$ at $37^{\circ} \mathrm{C}$ ), washed three times with Carnoy's fixative and cast on clean pre-cooled slides. To analyse the chromosomal aberrations the slides were stained with $10 \%$ Giemsa, air-dried and mounted with coverslip using DPX. Different types of aberrations were recoded as described earlier.

Micronucleus Assay: The blood samples were cultured in RPMI-1640 medium, supplemented with $20 \%$ fetal calf serum and $0.2 \mathrm{ml}$ PHA-M (Paul et al. 1997). Cytochalasin - B at a final concentration of $3 \mu \mathrm{g} / \mathrm{ml}$ culture was added at 44 hours of culture. The cells are further incubated for 28 hours at $37^{\circ} \mathrm{C}$. The cells were harvested with brief hypotonic treatment and slides were prepared by fixing the cells with Carnoy's fixative. The cell suspensions were dropped on to a clean cooled slide and stained with Giemsa. Cells with two daughter nuclei surrounded by cytoplasm were scored for the presence of MN.

Statistical Analysis: From the various types of aberrations recorded the aberration frequency was calculated as follows:

Aberration frequency $=$

Number of aberrations observed per sample

Number of metaphases scored per sample

The standard error for the aberration frequency was calculated as follows:

Standard error $=$

$\sqrt{\frac{\text { Number of aberrations observed per sample }}{\text { Number of metaphases scored per sample }}}$ 
Modulatory Factor: The modulatory effect of $2 \mathrm{DG}$ was calculated as given by Dwarakanath et al. (1987).

Dose modulatory factor $(\rho)=$

Drug induced aberration frequency with 2-DG

\section{Drug induced aberration frequency} without 2-DG

If $\rho>1=$ sensitising effect $\rho<1=$ protecting effect.

\section{RESULTS}

The PBL were exposed to bleomycin in the presence of 2-DG at $\mathrm{G}_{0}$ phase of the cells, which is the normal stage of majority of the cells in the body at any given time, which enables to some

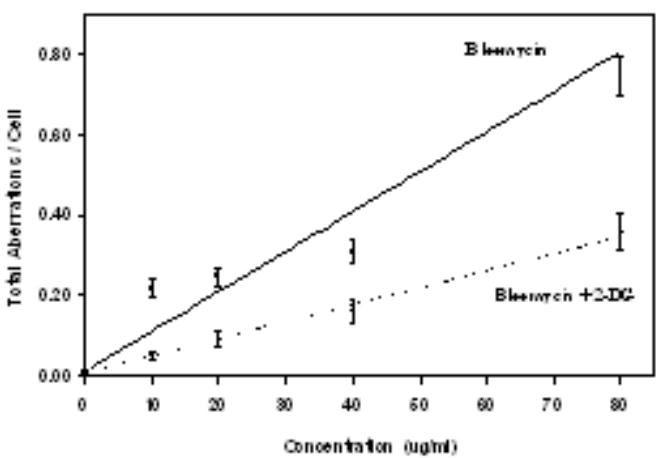

Fig. 1. Dose-response curve for total aberrations obtained from peripheral blood lymphocytes exposed to bleomycin with and without 2-deoxyD-glucose

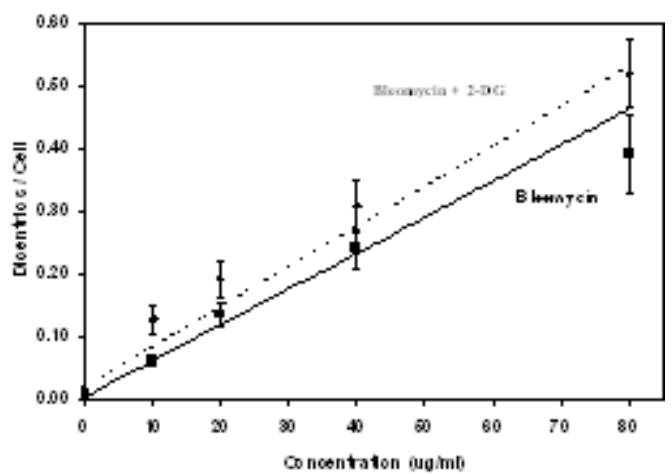

Fig. 3. Dose-response curve for total aberrations obtained from BMG-1 cells exposed to bleomycin with and without 2-deoxy-D-glucose extent that the overall response of tumors surrounding cell to therapeutic drugs. Similarly, the BMG-1 cells were exposed to bleomycin and 2-DG, which contain mixed population of dividing and non-dividing cells represent an approximate tumor condition. The $5 \mathrm{mM}$ concentration of 2DG was selected to get an equi-molar concentration of glucose in the normal blood samples and as that of tumor cells for comparison. The reason for the selection of the drug is due its similarity to ionizing radiation on the mechanism of induction of DNA damage (Povirk 1996).

Dose-response of Chromosomal Aberrations Induced by Bleomycin: The dose-response curve for the frequencies of total aberrations (TA) and dicentric chromosomes (DC) obtained from both PBL and BMG-1 cells treated with bleomycin in the presence and absence of 2-DG fitted using

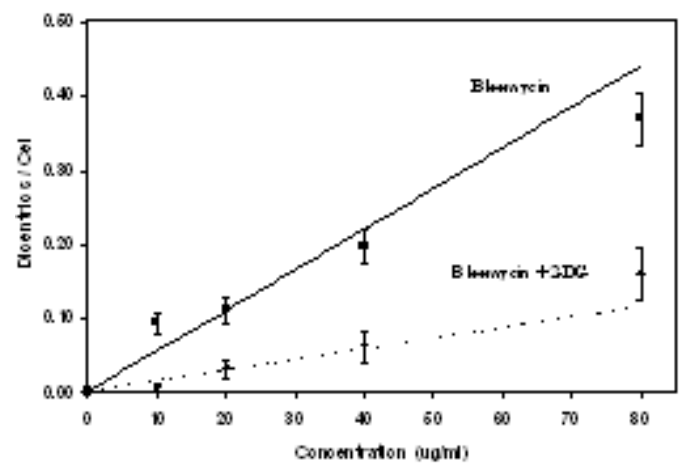

Fig. 2. Dose-response curve for dicentric chromosomes obtained from peripheral blood lymphocytes exposed to bleomycin with and without 2-deoxy-D-glucose

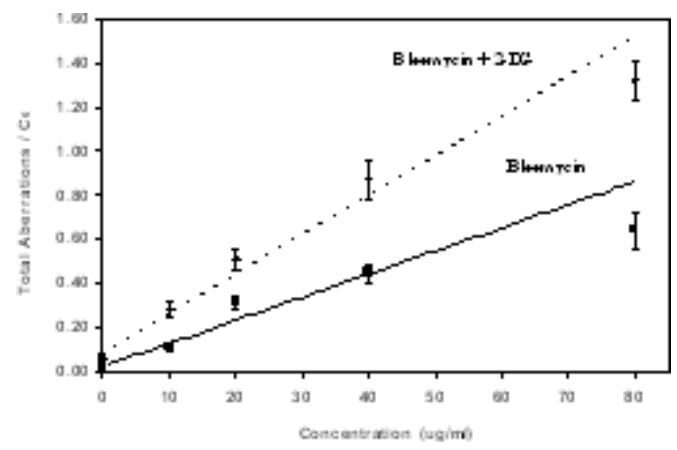

Fig. 4. Dose-response curve for dicentric chromosomes obtained from BMG-1 cells exposed to bleomycin with and without 2-deoxy-D-glucose 
a linear function are presented in Figures 1-4 respectively and the co-efficient are given in Table 1 . The linear co-efficient $(\alpha)$ was reduced from 0.0055 to 0.0014 for DC and 0.0098 to 0.0042 for TA, in PBL treated with bleomycin in the presence of 2-DG. Linear co-efficient $(\alpha)$ was increased from 0.0057 to 0.0064 for DC and 0.0105 to 0.0180 for TA in the BMG- 1 cells.

Chromosomal Aberrations and Micronuclei Induced by Bleomycin with and without 2-DG:

Chromosome aberrations have long been recognized to be an important biomarker of exposure to ionizing radiation and genotoxic chemicals. Frequencies of chromosomal aberrations (CA) and micronucleus (MN) obtained from peripheral blood lymphocytes (PBL) and BMG-1 cells treated with bleomycin are given in Tables 2-5 respectively. The base line frequencies of $\mathrm{CA}$ and $\mathrm{MN}$ obtained from PBL in the present study is comparable with that of our earlier results (Venkatachalam et al. 1999). In untreated BMG-1 cells, both CA and MN were higher when compared to that obtained in PBL $(\mathrm{P}=0.001)$. CA induced by bleomycin is two fold higher in both PBL and BMG-1 cells. However the exchange type chromosome aberrations (DC) did not show any difference compared to that of MN. Tables 69 show, the frequencies of $\mathrm{CA}$ and $\mathrm{MN}$ obtained from PBL and BMG-1 cells treated with bleomycin in the presence of 2-DG. When compared to bleomycin induced CA frequency, presence of 2DG reduced the aberration frequencies in PBL $(\mathrm{p}$ $<0.0001)$ and increased in BMG-1 ( $<<0.0001)$ cells with extremely significant. However in BMG1 cells treated with bleomycin in the presence of 2DG increases the MN frequency significantly, the reduction was not significant in the PBL in all the concentrations of the bleomycin.

Table 1: Coefficients of dose-response curves obtained from peripheral blood lymphocytes and BMG1 cells treated to bleomycin with and without 2-deoxy-D-glucose

\begin{tabular}{lrrr}
\hline Treatment & End point & $C \pm S E$ & $\alpha \pm S E$ \\
\hline Peripheral blood lymphocytes & & & \\
Bleomycin & DC & $0.0011 \pm 0.0009$ & $0.0055 \pm 0.0007$ \\
& TA & $0.0106 \pm 0.0114$ & $0.0098 \pm 0.0019$ \\
2-DG + Bleomycin & DC & $0.0009 \pm 0.0005$ & $0.0014 \pm 0.0003$ \\
$B M G-1$ Cells & TA & $0.0051 \pm 0.0004$ & $0.0042 \pm 0.0002$ \\
Bleomycin & & & \\
2-DG + Bleomycin & DC & $0.0048 \pm 0.0017$ & $0.0057 \pm 0.0003$ \\
& TA & $0.0214 \pm 0.0183$ & $0.0105 \pm 0.0016$ \\
& DC & $0.0198 \pm 0.0112$ & $0.0064 \pm 00011$ \\
\hline
\end{tabular}

$\mathrm{DC}=$ Dicentric chromosome

$\mathrm{TA}=$ Total aberrations

$\mathrm{C} \pm \mathrm{SE}=$ Control with standard error

$\alpha \pm \mathrm{SE}=$ Alpha with standard error

Table 2: Frequency of chromosome aberrations in peripheral blood lymphocytes exposed to bleomycin

\begin{tabular}{lccccc}
\hline $\begin{array}{l}\text { Concentration } \\
(\mu \mathrm{g} / \mathrm{ml})\end{array}$ & $\begin{array}{c}\text { Metaphases } \\
\text { scored }\end{array}$ & $\begin{array}{c}\text { Dicentric } \\
\text { chromosomes }\end{array}$ & $\begin{array}{c}\text { Total } \\
\text { aberrations }\end{array}$ & $\begin{array}{c}\text { Dicentrics / } \\
\text { Cell } \pm S E\end{array}$ & $\begin{array}{c}\text { Total Aberration / } \\
\text { Cell } \pm S E\end{array}$ \\
\hline 0 & 1983 & 2 & 16 & $0.001 \pm 0.007$ & $0.008 \pm 0.002$ \\
10 & 452 & 42 & 98 & $0.093 \pm 0.014$ & $0.217 \pm 0.022$ \\
20 & 436 & 48 & 107 & $0.110 \pm 0.016$ & $0.245 \pm 0.024$ \\
40 & 362 & 71 & 112 & $0.196 \pm 0.023$ & $0.309 \pm 0.029$ \\
80 & 305 & 118 & 228 & $0.368 \pm 0.036$ & $0.748 \pm 0.050$ \\
\hline
\end{tabular}

Table 3: Frequency of micronuclei in peripheral blood lymphocytes exposed to bleomycin*

\begin{tabular}{lcc}
\hline $\begin{array}{l}\text { Concentration } \\
(\mu \mathrm{g} / \mathrm{ml})\end{array}$ & $\begin{array}{c}\text { Number of } \\
\text { micronuclei }\end{array}$ & $\begin{array}{c}\text { MN frequency / } \\
\text { Cell } \pm \text { SE }\end{array}$ \\
\hline 0 & 5 & $0.005 \pm 0.002$ \\
10 & 24 & $0.024 \pm 0.005$ \\
20 & 75 & $0.075 \pm 0.009$ \\
40 & 100 & $0.100 \pm 0.010$ \\
80 & 247 & $0.247 \pm 0.015$ \\
\hline
\end{tabular}

*1000 binucleated scored from each sample
Modulatory Effect 2-DG on Bleomycin Induced Aberrations: The modulatory factor $(\rho)$ calculated for TA and DC and $\mathrm{MN}$ is given in Tables 10 and 11 for PBL and BMG-1 cells. In PBL, $\rho$ value varies between 0.24 and 0.42 for TA, 0.07 and 0.25 for DC and 0.1 to 0.83 for MN to different concentrations of bleomycin, showed the protective effect of 2-DG on bleomycin induced aberrations in normal cells. Whereas, in BMG-1 cells, $\rho$ value varies between 1.45 and 
Table 4: Frequency of chromosome aberrations in BMG-1 cells exposed to bleomycin

\begin{tabular}{lccccc}
\hline $\begin{array}{l}\text { Concentration } \\
(\mu \mathrm{g} / \mathrm{ml})\end{array}$ & $\begin{array}{c}\text { Metaphases } \\
\text { scored }\end{array}$ & $\begin{array}{c}\text { Dicentric } \\
\text { chromosomes }\end{array}$ & $\begin{array}{c}\text { Total } \\
\text { aberrations }\end{array}$ & $\begin{array}{c}\text { Dicentrics / } \\
\text { Cell } \pm S E\end{array}$ & $\begin{array}{c}\text { Total Aberration / } \\
\text { Cell } \pm \text { SE }\end{array}$ \\
\hline 0 & 431 & 2 & 8 & $0.005 \pm 0.003$ & $0.018 \pm 0.007$ \\
10 & 613 & 38 & 67 & $0.062 \pm 0.010$ & $0.109 \pm 0.013$ \\
20 & 426 & 58 & 133 & $0.136 \pm 0.018$ & $0.312 \pm 0.027$ \\
40 & 274 & 66 & 122 & $0.240 \pm 0.029$ & $0.445 \pm 0.040$ \\
80 & 102 & 40 & 65 & $0.392 \pm 0.062$ & $0.637 \pm 0.079$ \\
\hline
\end{tabular}

Table 5: Frequency of $M N$ in BMG-1 cells (log phase) exposed to bleomycin *

\begin{tabular}{lcc}
\hline $\begin{array}{l}\text { Concentration } \\
(\mu \mathrm{g} / \mathrm{ml})\end{array}$ & $\begin{array}{c}\text { Number of } \\
\text { micronuclei }\end{array}$ & $\begin{array}{c}\text { MN frequency / } \\
\text { Cell } \pm \text { SE }\end{array}$ \\
\hline 0 & 20 & $0.020 \pm 0.004$ \\
10 & 47 & $0.047 \pm 0.007$ \\
20 & 109 & $0.109 \pm 0.010$ \\
40 & 156 & $0.156 \pm 0.012$ \\
80 & 299 & $0.299 \pm 0.017$ \\
\hline
\end{tabular}

*1000 binucleated scored from each sample

2.59 for TA, 1.10 and 2.06 for DC and 1.16 to 1.66 for $\mathrm{MN}$ respectively, showed the sensitizing effect of 2-DG. The modulatory effect of 2-DG was seen at all concentrations of bleomycin studied.

\section{DISCUSSION}

Wide varieties of anti-neoplastic agents are used routinely in clinical oncology. Unfortunately majority of the drugs are toxic to normal tissues resulting from multi-drug protocol used to induce remissions and achieve tumor care. Radiomimetic agent bleomycin is a free radical-based DNA damaging agent, which induces double-strand
Table 7: Frequency of micronuclei in peripheral blood lymphocytes exposed to bleomycin in the presence of 2-deoxy-D-glucose *

\begin{tabular}{lcc}
\hline $\begin{array}{l}\text { Concentration } \\
(\mu \mathrm{g} / \mathrm{ml})\end{array}$ & $\begin{array}{c}\text { Number of } \\
\text { micronuclei }\end{array}$ & $\begin{array}{c}\text { MN frequency } / \\
\text { Cell } \pm S E\end{array}$ \\
\hline 0 & 5 & $0.005 \pm 0.002$ \\
10 & 20 & $0.020 \pm 0.005$ \\
20 & 49 & $0.049 \pm 0.007$ \\
40 & 76 & $0.076 \pm 0.009$ \\
80 & 181 & $0.181 \pm 0.013$ \\
\hline$*$
\end{tabular}

breaks by highly specific, concerted free radical attack on deoxyribose moieties in both DNA strands. The lesions induced by this 'radiomimetic' drug is thus actually only a small subset of the myriad lesions induced by ionizing radiation, yet effects of such radiomimetic agent on cells are remarkably similar to those of radiation (Sarto et al. 1990; Povirk 1996).

Exposure of cells to therapeutic agents induces variety of DNA lesions (Hall 2000). A double strand break is believed to be a most important lesion produced in chromosomes because, the cell killing is associated with double strand breaks, as double strand breaks can lead to chromosomal aberrations, which are lethal to

Table 6: Frequency of chromosome aberrations in peripheral blood lymphocytes exposed to bleomycin in the presence of 2 -deoxy-D-glucose

\begin{tabular}{lccccc}
\hline $\begin{array}{l}\text { Concentration } \\
(\mu \mathrm{g} / \mathrm{ml})\end{array}$ & $\begin{array}{c}\text { Metaphases } \\
\text { scored }\end{array}$ & $\begin{array}{c}\text { Dicentric } \\
\text { chromosomes }\end{array}$ & $\begin{array}{c}\text { Total } \\
\text { aberrations }\end{array}$ & $\begin{array}{c}\text { Dicentrics / } \\
\text { Cell } \pm S E\end{array}$ & $\begin{array}{c}\text { Total Aberration / } \\
\text { Cell } \pm S E\end{array}$ \\
\hline 0 & 1983 & 2 & 8 & $0.001 \pm 0.007$ & $0.005 \pm 0.001$ \\
10 & 468 & 3 & 21 & $0.006 \pm 0.004$ & $0.051 \pm 0.010$ \\
20 & 268 & 9 & 16 & $0.033 \pm 0.011$ & $0.093 \pm 0.019$ \\
40 & 204 & 13 & 20 & $0.064 \pm 0.018$ & $0.161 \pm 0.028$ \\
80 & 161 & 26 & 32 & $0.161 \pm 0.032$ & $0.360 \pm 0.047$ \\
\hline
\end{tabular}

Table 8: Frequency of chromosome aberrations in BMG-1 cells (log phase) exposed to bleomycin in the presence of 2-deoxy-D-glucose

\begin{tabular}{lccccc}
\hline $\begin{array}{l}\text { Concentration } \\
(\mu \mathrm{g} / \mathrm{ml})\end{array}$ & $\begin{array}{c}\text { Metaphases } \\
\text { scored }\end{array}$ & $\begin{array}{c}\text { Dicentric } \\
\text { chromosomes }\end{array}$ & $\begin{array}{c}\text { Total } \\
\text { aberrations }\end{array}$ & $\begin{array}{c}\text { Dicentrics / } \\
\text { Cell } \pm S E\end{array}$ & $\begin{array}{c}\text { Total Aberration / } \\
\text { Cell } \pm \text { SE }\end{array}$ \\
\hline 0 & 268 & 4 & 16 & $0.015 \pm 0.007$ & $0.059 \pm 0.014$ \\
10 & 226 & 29 & 64 & $0.128 \pm 0.023$ & $0.283 \pm 0.035$ \\
20 & 249 & 48 & 126 & $0.193 \pm 0.029$ & $0.506 \pm 0.045$ \\
40 & 110 & 37 & 96 & $0.309 \pm 0.042$ & $0.872 \pm 0.080$ \\
80 & 102 & 60 & 92 & $0.431 \pm 0.055$ & $0.902 \pm 0.090$ \\
\hline
\end{tabular}


Table 9: Frequency of chromosome aberrations in BMG-1 cells (log phase) exposed to bleomycin in the presence of 2-deoxy-D-glucose

\begin{tabular}{lcc}
\hline $\begin{array}{l}\text { Concentration } \\
(\mu \mathrm{g} / \mathrm{ml})\end{array}$ & $\begin{array}{c}\text { Number of } \\
\text { micronuclei }\end{array}$ & $\begin{array}{r}\text { MN frequency } \\
\text { Cell } \pm S E\end{array}$ \\
\hline 0 & 18 & $0.018 \pm 0.004$ \\
10 & 78 & $0.078 \pm 0.008$ \\
20 & 139 & $0.139 \pm 0.012$ \\
40 & 181 & $0.181 \pm 0.013$ \\
80 & 373 & $0.373 \pm 0.019$ \\
\hline$* 1000$ binucleated scored from each sample
\end{tabular}

Table 10: Modulatory factor of 2-deoxy-D-glucose on the frequency of chromosome aberrations in peripheral blood lymphocytes exposed to bleomycin

\begin{tabular}{lccc}
\hline $\begin{array}{l}\text { Concentration } \\
(\mu \mathrm{g} / \mathrm{ml})\end{array}$ & $\begin{array}{c}\text { Dicentric } \\
\text { chromosomes }\end{array}$ & $\begin{array}{c}\text { Total } \\
\text { aberrations }\end{array}$ & $M N$ \\
\hline 10 & 0.07 & 0.72 & 0.55 \\
20 & 0.30 & 0.38 & 0.84 \\
40 & 0.33 & 0.52 & 0.10 \\
80 & 0.44 & 0.48 & 0.83 \\
\hline
\end{tabular}

Table 11: Modulatory factor of 2-deoxy-D-glucose on the frequency of chromosome aberrations in BMG-1 cells (log phase) exposed to bleomycin

\begin{tabular}{lccc}
\hline $\begin{array}{l}\text { Concentration } \\
(\mu \mathrm{g} / \mathrm{ml})\end{array}$ & $\begin{array}{c}\text { Dicentric } \\
\text { chromosomes }\end{array}$ & $\begin{array}{c}\text { Total } \\
\text { aberrations }\end{array}$ & $M N$ \\
\hline 10 & 2.06 & 2.60 & 1.66 \\
20 & 1.42 & 1.62 & 1.27 \\
40 & 1.29 & 1.96 & 1.16 \\
80 & 1.10 & 1.42 & 1.25 \\
\hline
\end{tabular}

the cells. Results obtained in the present study showed that though bleomycin induces variety of chromosomal aberrations in both PBL and BMG-1 cells, of which 60 to $70 \%$ of them are dicnetric chromosomes, would have resulted due to restitution of double strand breaks from two different chromosomes; remaining includes simple chromosome and chromatid type lesions without any exchanges. The results are in agreement with earlier reports obtained from $\mathrm{CHO}$ cells (Kurten et al. 1990) and PBL obtained from patients treated with bleomycin (Schnizel et al. 1976; Obe et al. 1981), in which the dicentric chromosomes account for $90 \%$ of aberrations. The MN frequencies induced by bleomycin is less $(\sim 50 \%)$ when compared to CA, for the same concentration of the drug. This is probably due to the mechanism of formation of $\mathrm{MN}$ and its elimination. It has been demonstrated that $\mathrm{MN}$ are produced during mitosis from broken chromosomes or whole chromosome, which fails to incorporate into daughter nucleus, damaged kinetochores or spindle fiber defects (Muller et al. 1996). MN can get included into the daughter nucleus (Savage 1988) or masking of MN by the daughter nucleus (Paul et al. 1997) and fusion of more than one damage in the formation of $\mathrm{MN}$ (Littlefield et al. 1989) or eliminated from cells (e.g. expulsion, inclusion in nucleus in mitosis, cell death) (Ford et al. 1988), are the suggested reasons for the less yield of $\mathrm{MN}$ when compared to $\mathrm{CA}$ induced by ionizing radiation. Furthermore, it was also shown that the content and amount of MN will differ depending upon the agent induces the DNA damages (Norppa et al. 2003). However, the reason is unclear for the lower frequency of $\mathrm{MN}$ than CA induced by bleomycin obtained in the present study.

It has been demonstrated that 2-DG sensitized the radiation induced DNA damages in tumor cells (Jain et al.1977) while providing protection to such damages in normal cells (Kalia et al. 1982). The bleomycin induced $\mathrm{CA}$ and $\mathrm{MN}$ frequencies in PBL and BMG-1 cells, showing a linear relation (Figure 1 and 2 and Table -2 and 5). While the presence of 2-DG, showed an extremely significant reduction in the frequencies of CA in the PBL $(r<$ 1) at all the bleomycin concentrations studied, the MN shows a significant reduction. On the other hand, 2-DG showed a very significant enhance in both CA and $\mathrm{MN}$ frequencies induced by bleomycin in BMG-1 cells $(r>1)$. These results suggest that $2 \mathrm{DG}$ protect the chemotherapeutic drug induced cytogenetic damages especially exchange type chromosome aberrations in normal cells while sensitizing the tumor cells.

Mechanisms proposed for the reduction of damages on normal cells during radiation treatment are (I) Protecting the DNA against the induction of damage, (II) interference with the progression of cells in cell cycle and (III) modifications of repair of damages. Earlier we had shown evidence that exposure of cells to 2DG increases the average generation time in normal cells (Venkatachalam et al. 2006). The drug induced transient block in cell cycle progression, presumably permit the error free repair of DNA damages before the cell initiate the synthesis or mitosis in normal cells. In tumor cells, the rate of fixation is higher and therefore increased number of DNA lesions caused by decrease in DNA repair in the presence of 2-DG, would immediately transformed in to irreparable lesions, which are expressed as chromosomal aberrations. Jain et al. (1985) had demonstrated the energy dependency to repair the radiation induced $\mathrm{MN}$ 
frequencies in BMG-1 cells. It was shown that ATP synthesis and oxidative metabolism were essential for the repair of damages induced by radiation (Dwarakanath et al. 1989). Since gliomas are heterogeneous in nature and more efficient in there repair system, they are more resistant to therapy (Timperly 1980). Therefore it has been suggested that 2-DG in combination with radiotherapy/chemotherapy could lead to an improvement in tumor therapy by inhibiting the repair process and enhance the damage by fixing the lesions in tumor cells while protecting the normal cells.

\section{ACKNOWLEDGEMENTS}

The authors wish to thank the DRDO, Government of India and Council of Scientific and Industrial Research (CSIR) for providing the financial assistance to carry our research work.

\section{REFERENCES}

Aft RL, Zhang WF, Glus D 2006. Evaluation of 2-deoxyD-glucose as a chemotherautic agent: mechanism of cell death. Br J Cancer, 87: 805-812.

Bleehen NM, Gillies E, Twentyman PR 1974. The effect of bleomycin and radiation in combination on mammalian cells in culture. Br J Radiol, 47: 346351 .

Cloos JB, Reid A, vander Sterre LT, Tobi H, Leemans GR, Snow, GB, Braakhuis JM 1999. A comparison of bleomycin-induced damage in lymphocytes and primary oral fibroblasts and keratinocytes in 30 subjects. Mutagenesis, 14: 87-93.

de Madsa RL, de Cerain AL, Ariznabarreta LS, Abinzano, MJC, Patino-Garecia A 2002. Measurement and analysis of the chemotherapy induced genetic instability in pediatric cancer patients. Mutagenesis, 17: $171-175$

Denison L, Haigh A, D’Cunha G, Martin RF 1992. DNA ligants as radioprotectors: Molecular Studies with Hoechest 3342 and Hoechest 33258. Int J of Radiat Biol, 61: 69.

Dwarakanath BS, Jain VK 1987. Modification of the radiation induced damage by 2 -deoxy-D-glucose in organ cultures of human cerebral Gliomas. Int $J$ Radiat Oncol Biol Phys, 13: 741-746.

Dwarakanath BS, Jain VK 1989. Energy linked modifications of the radiation response in a human cerebral glioma cell line. Int J Radiat Oncol Biol Phys, 17: 1033-1040.

Ford JH, Schultz CJ, Correll AT 1988. Chromosome elimination in micronuclei: a common cause of hypoploidy. Am J Hum Genet, 43: 733-740.

Hall EJ 2000. DNA strand breaks and chromosome aberrations. Radiobiology for the Radiologist. Fifth edition, Lippincott: Williams and Wilkins, pp. 1732.
Franchitto P, Pichierri P, Mosesso F, Palitti F 1998. Caffeine effect on the mitotic delay induced by $\mathrm{G} 2$ treatment with UVC or mitomycin-C. Mutagenesis, 13: 499- 505.

IAEA Technical Report 1986. Biological dosimetry, chromosome aberration analysis for dose assessment. In: Technical report series No 20. Vienna; IAEA, pp 1-69.

Jain VK, Kalia VK, Gopinath PM, Naqvi S, Kucheria K 1979. Optimization of cancer therapy: Part IIIEffect of combining 2-deoxy-D-glucose treatment with gamma-irradiation on normal mice. Ind $J$ Exp Biol, 17: 1320-1325.

Jain VK, Kalia VK, Sharma R, Maharajan V, Menon M 1985. Effects of 2-Deoxy Glucose on glycolysis, proliferation kinetics and radiation response of human cancer cells. Int J Radiat Oncol Biol Phys, 11: $943-950$.

Jain VK, Prohit SC, Ponlit W 1977. Optimization of cancer therapy: part I-Inhibition of repair of X-ray induced potentially lethal damage by 2 -deoxy-Dglucose in Ehenlich-ascites tumor cells. Ind $J$ Exp Biol, 15: 711-713

Kalia VK, Jain VK, Otto FJ 1982. Optimization of cancer therapy IV: Effects of $2 \mathrm{DG}$ on radiation induced chromosomal damage in PHA stimulated human leukocytes. Ind J Exp Biol, 20: 884-888.

Kurten S, Obe G 1990. Premature chromosome condensation in the bone marrow of Chinese hamster ovary cells after application of bleomycin in vivo. Mutat Res, 228: 157-169.

Littlefield LG, Sayer AM, Frome EL 1989. Comparison of dose-response parameters for radiation induced acentric fragments and micronuclei observed in cytokinesis arrested lymphocytes. Mutagenesis, 4: 265-270.

Muller WU, Nusse M, Miller BM, Slavotinek A, Viaggi S, Streffer C 1996. Micronuclei: a biological indicator of radiation damage. Mutat Res, 366: 163-169.

Norppa H, Falck GC 2003. What to human micronuclei contain? Mutagenesis, 18: 221-233.

Obe G, Matthiessen W, Gobel D 1981. Chromosomal aberrations in the peripheral blood lymphocytes of cancer patients treated with high-energy electrons and bleomycin. Mutat Res, 81: 133-141.

Pattet HM, Tyree EV, Straube RL, Smith DE 1949. Cystein protection against $\mathrm{X}$ irradiation. Science, 110: 213.

Paul, SFD, Venkatachalam P, Jeevanram RK 1997. Analysis of radiation dose-response curve obtained with cytokinesis block MN assay. Nuclear Medicine and Biology, 24: 413-416.

Povirk, LF 1996 DNA damage and mutagenesis by radiomimetic DNA-cleaving agents: bleomycin, neocarzinostatin and other enediynes. Mutat Res, 355: 71-89.

Rajeev V, Kale RK 1995. Modulation of radiation induced lipid peroxidation by phospholipase A2 and calmodulin antagonists: Relevance to detoxification. Radiat Phys Chem, 45: 671.

Savage, RKJ 1988, A comment on the quantitative relationship between micronuclei and chromosomal aberrations. Mutat Res, 207: 33-36.

Salpak D, Kufe W 1986, Principles of cancer therapy. 
In: Principles of Internal Medicine; $13^{\text {th }}$ edition, Harrison Publications, 1827-1839.

Sarto F, Tomanin R, Giacomelli L, Canova A, Raimondi F, Ghiotto C, Fiorentino MV 1990. Evaluation of chromosomal aberration in lymphocytes and micronucleus in lymphocytes, oral mucosa and hair root cells of patients under antiblastic therapy. Mutat Res, 228: 157-169.

Schnizel W, Schmid W 1976. Lymphocyte chromosome studies in humans exposed to chemical mutagens. The validity of the method in 67 patients under cystostatic therapy. Mutat Res, 40: 139-166.

Shrivastava V, Mishra AK, Dwarakanath BS, Ravindranath 2006. Enhancement of radionuclide induced cytotoxicity by 2-deoxy-D-glucose in human tumor cell lines. Cancer Therapeutics, 2: 57-64.

Timperly WR 1980. Glycolysis in neuro-ectodermal tumors. In: Brain Tumors-Scientific Basis, Clinical Investigation \& Current Therapy, D.G.T. Thomas
\& D.I. Graham (Eds). London, Butterworths. pp. 145-167.

Venkatachalam P, Paul SFD, Mohankumar MN, Prabhu BK, Kathiresan A, Jeevanram RK 1999. Higher frequency of dicentrics and micronuclei in peripheral blood lymphocytes of cancer patients. Mutat Res, 425:1-8.

Venkatachalam P, Jayanth, VR, Paul SFD, Vettriselvi, V 2006. Protective effect of 2-deoxy-D-glucose on chemotherapeutic drugs induced damages on peripheral blood lymphocytes exposed in-vitro. Int J Hum Genet, 6:133-138.

Vral A, Thierens H, Baeyens A, Ade Ridder L 2004. Chromosomal aberrations and in-vitro radio sensitivity: intra-individual versus inter-individual variability. Toxicol Lett, 149: 345-352.

Watters JW, Mcleord HL 2003, Cancer pharmacogenomics: current and future directions. Biochem Biophy Acta, 1603: 99-111. 